\title{
Local Community Satisfaction toward Tourism Development in Pushkar Region of Rajasthan, India
}

\author{
Sunil Tiwari ${ }^{1}$ (D), Natalia Tomczewska-Popowycz ${ }^{2, *}$, , Shiv Kumar Gupta ${ }^{3}$ and Magdalena Petronella Swart ${ }^{4}$ \\ 1 University Institute of Tourism and Hotel Management (U.I.T.H.M.), Chandigarh University, \\ Mohali 140413, Punjab, India; tiwari.sunil10@outlook.com \\ 2 Faculty of Natural Sciences, Institute of Socio-Economic Geography and Spatial Management, \\ University of Silesia, Bedzinska 60 Str., Sosnowiec 41-200, Poland \\ 3 Centre for Mountain Tourism and Hospitality Studies, Hemvati Nandan Bahuguna, \\ Garhwal Central University, Srinagar 246174, Uttarakhand, India; sk.gupta@hnbgu.ac.in \\ 4 School of Public and Operations Management, University of South Africa, Pretoria 0002, South Africa; \\ swartmp@unisa.ac.za \\ * Correspondence: natalia.tomczewska-popowycz@us.edu.pl
}

Citation: Tiwari, S.; TomczewskaPopowycz, N.; Gupta, S.K.; Swart, M.P. Local Community Satisfaction toward Tourism Development in Pushkar Region of Rajasthan, India Sustainability 2021, 13, 13468.

https://doi.org/10.3390/su132313468

Academic Editor: Colin Michael Hall

Received: 16 October 2021

Accepted: 2 December 2021

Published: 6 December 2021

Publisher's Note: MDPI stays neutral with regard to jurisdictional claims in published maps and institutional affiliations.

Copyright: (c) 2021 by the authors. Licensee MDPI, Basel, Switzerland. This article is an open access article distributed under the terms and conditions of the Creative Commons Attribution (CC BY) license (https:/ / creativecommons.org/licenses/by/ $4.0 /)$.

\begin{abstract}
Satisfaction of local residents is one of the key factors in responsible and sustainable tourism development. It helps tourism planners and policymakers in effective and strategic utilization of tourism resources. The present study investigates local residents' satisfaction level toward sustainable tourism development through economic, socio-cultural, and environmental development. In order to achieve the goal of the study, one-sample $t$-test, regression analysis, and Structural Equation Modeling (SEM) were performed. The findings of the study have suggested that local residents have a different level of satisfaction towards overall sustainable development and economic, sociocultural, and environmental development in the study area. It was also observed that there is a high positive correlation among economic, socio-cultural, and environmental developments, and these developments significantly impact sustainable tourism development.
\end{abstract}

Keywords: sustainable tourism development; satisfaction; economic development; environmental impact; Pushkar; structural equation modeling (SEM)

\section{Introduction}

Tourism has been recognized as one of the largest and fastest-growing industries globally, generating $10.4 \%$ of Gross Domestic Product (GDP) in 2019 and decreasing to 5.5\% in the year 2020 due to ongoing travel restrictions caused by the COVID-19 pandemic [1]. Tourism development transforms a destination in several ways, and it results in many negative and positive outcomes. All the components of tourism, such as attractions, accessibility, accommodation, amenities, and activities at destination, impact and alter each aspect of a destination, such as its physical, social, cultural, economic, and environmental aspects, in both positive and negative ways [2]. Natural and cultural environments are essential pull-factor components for a destination to work as a tourism destination. The growth and development of a tourism destination are elucidated by [3], with the help of the Destination Life Cycle or Tourism Area Life Cycle (TALC) model with stages such as: exploration, involvement, development, consolidation, stagnation, and decline or rejuvenation. According to the destination life cycle, a destination needs to pass through various stages of growth and development, as the volume and number of tourists keep increasing. Once a destination reaches its stagnation stage, it faces several cumulative impacts on the local economy, culture, society, and the environment $[4,5]$. Mass tourism increases the consumption of tourism products and resources, creating an imbalance between demand and supply and causing negative impacts on tourism destinations [6,7]. The carrying capacity of a destination and its impacts on a destination, local residents, tourists, and stakeholders, 
is another important component for determining and measuring tourism impacts [2]. In the case of natural tourism products and resources, these impacts are more intense due to more fragility and limitations of natural resources [8]. The fundamental reason for environmental problems is the personal gains of local residents and other stakeholders [9]. However, the relationship between residents, tourists, other stakeholders, and the environment would also alter because of transformations in tourism destinations [10]. Economic benefits of tourism are well known to tourists, local residents, and other associated stakeholders [11]. However, these benefits are associated with cultural and environmental costs that are caused due to personal interests and irresponsible and unsustainable practices followed by tourists, local residents, and stakeholders [12]. Local residents are the most important and legitimate stakeholders over the destinations, and their participation is essential for responsible and sustainable tourism development [13]. Residents have the feeling of annoyance and antagonism toward mass tourism development, as they face problems such as cultural clashes, economic leakages, congestion, noise, demonstration effects, crime, high competition, and environmental dereliction, which further decrease satisfaction level of local residents toward tourism development $[14,15]$. There is a need for resources, such as land, electricity, energy, water, land, infrastructure, and natural and man-made attractions for developing tourism, but local communities use these resources. It is essential to seek active participation of local communities while planning, designing, and developing tourism [4]. In addition to local communities, these resources are also for the use of tourists in the form of tourism amenities and activities [16,17]. Therefore, a friendly relationship between tourists and local residents must be encouraged and ensured [18,19]. Tourism cannot be developed sustainably without the active support of local residents [20].

The present study provides a comprehensive framework and plays an important role in developing tourism destinations in responsible and sustainable ways. Thus, the aim of the present study is to investigate sustainable tourism development in the study area from the residents' point of view, via socio-cultural, economic, and environmental developments. Furthermore, for achieving the aim of the study, the following three objectives have been formulated:

1. To measure the satisfaction level of local residents toward sustainable tourism development.

2. To measure the impact of socio-cultural, economic, and environmental developments on sustainable tourism development.

3. To understand the relationship among socio-cultural, environmental, economic, and sustainable tourism developments.

This article contributes to the literature by comparing different types of tourism development and their impact on sustainable development. Concerning the above-mentioned objectives, the following hypotheses were formulated:

Hypothesis 1 (H1). Local residents have a high level of satisfaction toward sustainable tourism development in the Pushkar region of Rajasthan.

Hypothesis 2 (H2). Socio-cultural, economic, and environmental developments have no significant impact on sustainable tourism development and.

Hypothesis 3 (H3). Socio-cultural, economic, environmental, and sustainable tourism developments have a positive relationship.

This study contributes to tourism literature by developing a coherent, comprehensive, and comparative understanding of the role of local residents' satisfaction and the impact of tourism on economic, socio-cultural, and environmental changes.

The structure of the article is as follows: Section 2 discusses the peculiarities of the research area; the next Section deals with study design and the individual steps taken during the research; Section 4 presents the results of the research, and the final section is dedicated to discussions, recommendations, and limitations. 


\section{Study Area-Pushkar, India}

Pushkar is located in the Ajmer district of the Rajasthan province of India, about $10 \mathrm{~km}$ northwest and $150 \mathrm{~km}$ southwest from Ajmer and Jaipur, respectively, on the western side of the Aravalli Mountains. It lies between north latitude $26^{\circ} 29^{\prime} 23^{\prime \prime}$ and east longitude $74^{\circ} 33^{\prime} 3^{\prime \prime}$ (Figure 1). It is an important pilgrimage destination for Hindus and Sikhs, with more than 400 magnificent temples, including the only Lord Brahma temple in the entire world, along with the Pushkar Lake, bathing Ghats, and the famous Gurdwaras for Guru Nanak and Guru Gobind Singh. It is a lively tourist destination that always resounds with the chanting of prayers, religious songs, drums, and gongs, and thousands of tourists keep flocking around the city throughout the year.

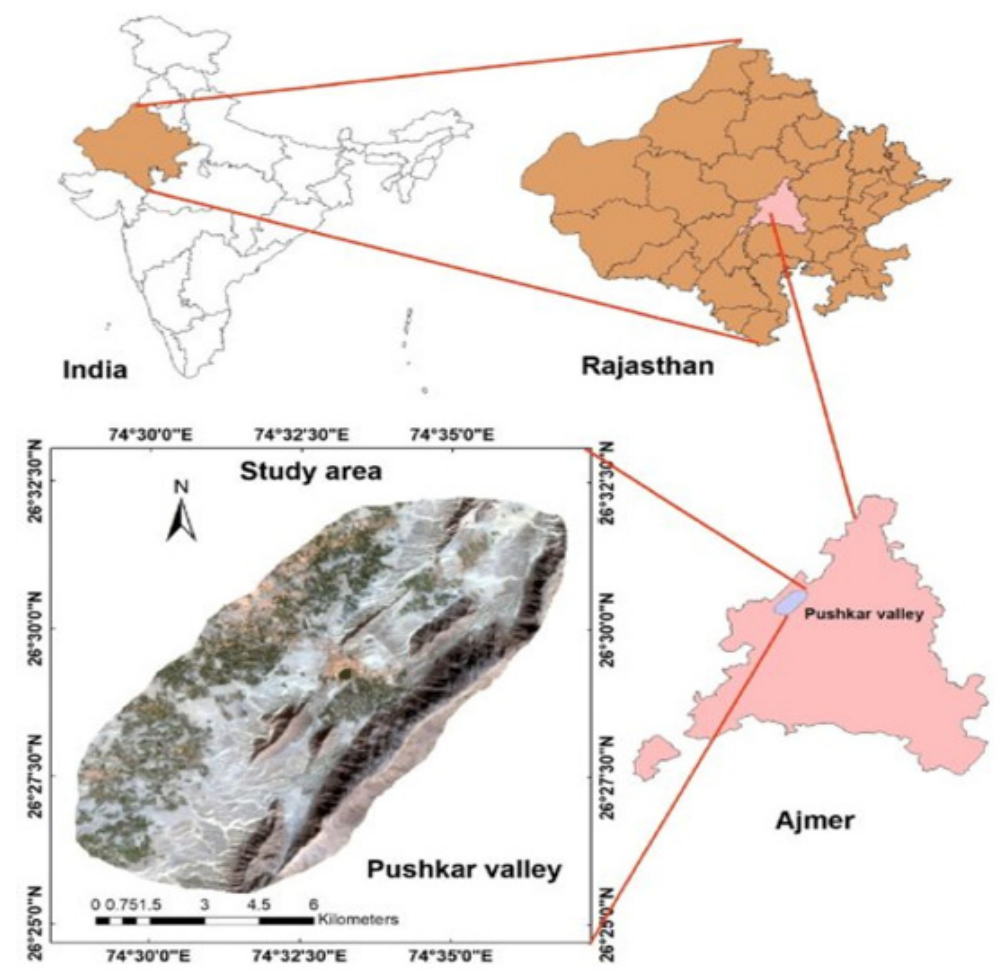

Figure 1. Location map of studied area-Pushkar, India. Source: https://ecologicalprocesses. springeropen.com/articles/10.1186/s13717-019-0193-5/figures/10 (accessed on 12 July 2021.)

Pushkar is a well-known tourist destination across India and the world, and tourism has been an essential part of its social, cultural, economic, and environmental development for several decades. Around 1.2 million domestic and international tourists visit Pushkar for its world-renowned and only Lord Brahma (Creator of Universe) temple in the world, the Ghats, Pushkar Lake, mythology, religious significance, spirituality, culture, cuisine, artefacts and handicraft, and the most popular annual international Camel Fair, which is one of the largest cattle festivals in the world. As shown in Table 1, the number of domestic and international tourist arrivals has increased substantially from 2010 to 2019 during the fair and regular days of the year. The Pushkar Fair (celebrated over a week in October or November during the time of Kartika Purnima, according to the Hindu calendar) contributes around 35\% of total tourist arrivals to Pushkar.

The increasing number of tourist arrivals reflects the popularity and demand of Pushkar as a tourist destination. Over time, the natural environment of Pushkar has been completely changed and gave way to infrastructure development to meet the demand of a large number of tourists. The carrying capacity of the destination is challenging, especially during fair time. Due to tourism, the price of land, water, energy, accommodation, and tourism products and services have been increasing, and several adverse impacts, such as pollution, loss of natural vegetation and landscape, degradation of the natural environ- 
ment, the worsening condition of Ghats and temples, congestion, and cultural dilution and commodification have been observed. These adverse impacts are due to irresponsible and unsustainable tourism practices being followed by tourists, local residents, and stakeholders for their personal gains and vested interests. This study measures local residents ${ }^{\prime}$ satisfaction toward sustainable tourism development in Pushkar in order to understand existing problems more keenly and specifically.

Table 1. Tourist arrivals in Pushkar (2010-2019).

\begin{tabular}{|c|c|c|c|c|c|c|c|c|}
\hline \multicolumn{4}{|c|}{ Tourist Arrivals at Non-Fair Days } & \multicolumn{5}{|c|}{$\begin{array}{l}\text { Tourist Arrivals during Fair } \\
\text { Total Tourist Arrivals }\end{array}$} \\
\hline Year & $\begin{array}{c}\text { Domestic } \\
\text { Tourists }\end{array}$ & Foreigners & Total & $\begin{array}{c}\text { Domestic } \\
\text { Tourists }\end{array}$ & Foreigners & Total & $\begin{array}{c}\% \text { of Total } \\
\text { Tourists }\end{array}$ & $\begin{array}{l}\text { Fair and } \\
\text { Non-Fair }\end{array}$ \\
\hline 2010 & 736,566 & 4803 & 741,369 & 211,133 & 2101 & 213,234 & $28.76 \%$ & 954,603 \\
\hline 2011 & 807,334 & 5003 & 812,337 & 241,007 & 2229 & 243,236 & $29.94 \%$ & $1,055,573$ \\
\hline 2012 & 836,298 & 6023 & 842,321 & 239,833 & 3406 & 243,239 & $28.87 \%$ & $1,085,560$ \\
\hline 2013 & 866,047 & 6301 & 872,348 & 257,053 & 6208 & 263,261 & $30.17 \%$ & $1,335,609$ \\
\hline 2014 & 955,730 & 6623 & 962,353 & 291,027 & 11,209 & 302,236 & $31.40 \%$ & $1,264,589$ \\
\hline 2015 & 987,542 & 6806 & 994,348 & 311,307 & 11,905 & 323,212 & $32.50 \%$ & $1,317,560$ \\
\hline 2016 & $1,035,383$ & 7013 & $1,042,396$ & 313,710 & 19,213 & 332,923 & $31.93 \%$ & $1,375,309$ \\
\hline 2017 & $1,085,440$ & 7102 & $1,092,542$ & 373,135 & 23,102 & 393,135 & $35.98 \%$ & $1,485,677$ \\
\hline 2018 & $1,135,037$ & 7304 & $1,142,341$ & 386,025 & 27,211 & 413,236 & $36.17 \%$ & $1,555,577$ \\
\hline 2019 & $1,184,802$ & 7543 & $1,192,345$ & 391,041 & 32,193 & 423,234 & $35.49 \%$ & $1,615,579$ \\
\hline
\end{tabular}

Source; Rajasthan Tourism Development Corporation (RTDC).

\section{Literature Review}

Sustainable tourism development (STD) is the long-term approach toward tourism growth and development without harming any aspect of the destination, local residents, tourists, and stakeholders, while simultaneously ensuring equal and fair distribution of tourism products, resources, costs, and benefits [21]. To ensure responsible and sustainable tourism development at any destination, tourists, local residents, and stakeholders need to work together, take collective decisions about tourism development, and strictly follow sustainable tourism practices [22]. STD creates a balance between physical and cultural environments of the destination [23]. The cooperation of local communities is necessary for responsible and sustainable tourism development; otherwise, it will benefit only a few stakeholders [10]. Indigenous culture, cuisine, community, and the environment must be protected and promoted to keep local residents satisfied with tourism development across destinations $[24,25]$. With the help of collective efforts of all the public and private stakeholders, the objective of sustainability could be achieved [13]. It is the responsibility of the government to develop tourism infrastructures, such as hotels, roads, airports, theme parks, amenities, tourist centers, etc., and create equal opportunities for all stakeholders [26]. Over time, several studies have been conducted on locals' satisfaction as a tool for sustainable tourism development [27-32].

Due to tourism development, local residents benefit from employment opportunities and economic benefits, and they can protect and promote indigenous culture, cuisine, and heritage [32,33]. Residents who experience better economic benefits are more supportive of and cooperative with tourism development at destinations [34]. The tourism development process could be controlled through the perception and satisfaction of local residents toward tourism. Local residents with a voice in tourism planning and development at destinations have a more positive perception and satisfaction toward tourism development [35]. When residents perceive the impact and benefits of tourism negatively, they have a low level of satisfaction toward tourism development [36]. There are several ways to develop 
tourism responsibly and sustainably, but a few specific indicators, tools, and guidelines are required to assess, evaluate, and test tourism development under the sustainability framework [37]. Audit and valuation of tourism resources are effective sustainability tools for evaluating costs and benefits of tourism development at tourism destinations [25]. Setting parameters for tourism growth and development, such as carrying capacity and acceptable change, could also make a huge contribution toward sustainable development $[2,5,38]$. The conceptual model of [39] is also quite popular and useful for sustainable tourism development, as this model designed some specific indicators to measure the physical, social, cultural, economic, and environmental impacts of tourism at the destination. In all such approaches, strong cooperation and coordination among governments, tourists, and local residents should be required at each level [40], and tourism needs to develop according to the needs and wants of local communities [41-45].

Several studies were conducted on various aspects of Pushkar connected to tourism: culture, cuisine, Pushkar Fair, cultural heritage $[46,47]$. The perception of tourists and satisfaction toward tourism development in Pushkar were studied by [48], stakeholders' satisfaction toward sustainable tourism development was studied by [49], and the foreign tourist satisfaction in Pushkar was studied by [50]. The impact of tourism development on natural resources was presented by [51]. There are also surveys connected to tourist satisfaction with hotels, festivals, and the condition of cultural heritage in Pushkar [52-54].

Moreover, several studies have been conducted on designing and developing methods, models, and scales for the measurement of perception, attitudes, and satisfaction of local residents toward different aspects of tourism, such as community development, economic development, socio-cultural development, environmental development, community attributes, and support for tourism, employment generation, regional and infrastructure development, and various other components of tourism in relation to local communities [55-58]. No previous study has been designed on any such scale for the investigation of local residents' satisfaction toward tourism development through socio-cultural, economic, and environmental development as core indicators of responsible and sustainable tourism development. This makes the present study innovative through the use of a constructed scale; locals' satisfaction measure scale (LSMS) is specific, unique, and uncommon compared to previous scales used, and it has wider significance and usage while developing responsible and sustainable tourism.

It was found that there is a dearth of literature regarding sustainable tourism development in Pushkar, India, concerning locals' satisfaction toward economic, socio-cultural and environmental development in the region. Based on this research gap, research objectives, hypotheses, studied variables, and a research framework were designed for the present research work.

\section{Research Design and Methodology}

The present study is empirical and exploratory in nature, conducted through normative survey method and qualitative and quantitative research methods under three phases:

Step 1. In the first phase of the study, a standardized tool was constructed-the locals' satisfaction measure scale (LSMS) measures the satisfaction level of local residents toward sustainable tourism development in the study area under socio-cultural, economic, and environmental parameters of sustainability. It comprises a total of 22 items under 3 categories, i.e., economic impact ( 7 items: jobs for local community, prices of goods and services, residents' income, quality of services, new markets, local entrepreneurship, infrastructure and public services improvement), socio-cultural impact (8 items: cultural activities, awareness of local heritage, preservation of local art, culture, and heritage, acculturation, living standards, changes in traditions and social norms, insecurity, social abuse), and environmental impact (7 items: urbanization, traffic congestion, environmental conservation, protection of natural habitats, destruction of natural environment, irritation due to tourism facilities, pollution). The statements assigned to each category are included in Appendix $\mathrm{A}$ of the questionnaire. 
Step 2. Under the second phase, a self-constructed standardized tool (LSMS) was administered to local residents of Pushkar, Rajasthan, from January 2019 to July 2019 and 5 to 12 November (during the Pushkar international festival).

Step 3. In the last phase of the study, data collected from local residents were empirically and qualitatively analyzed, and based on research findings, conclusions and recommendations were made (Figure 2).

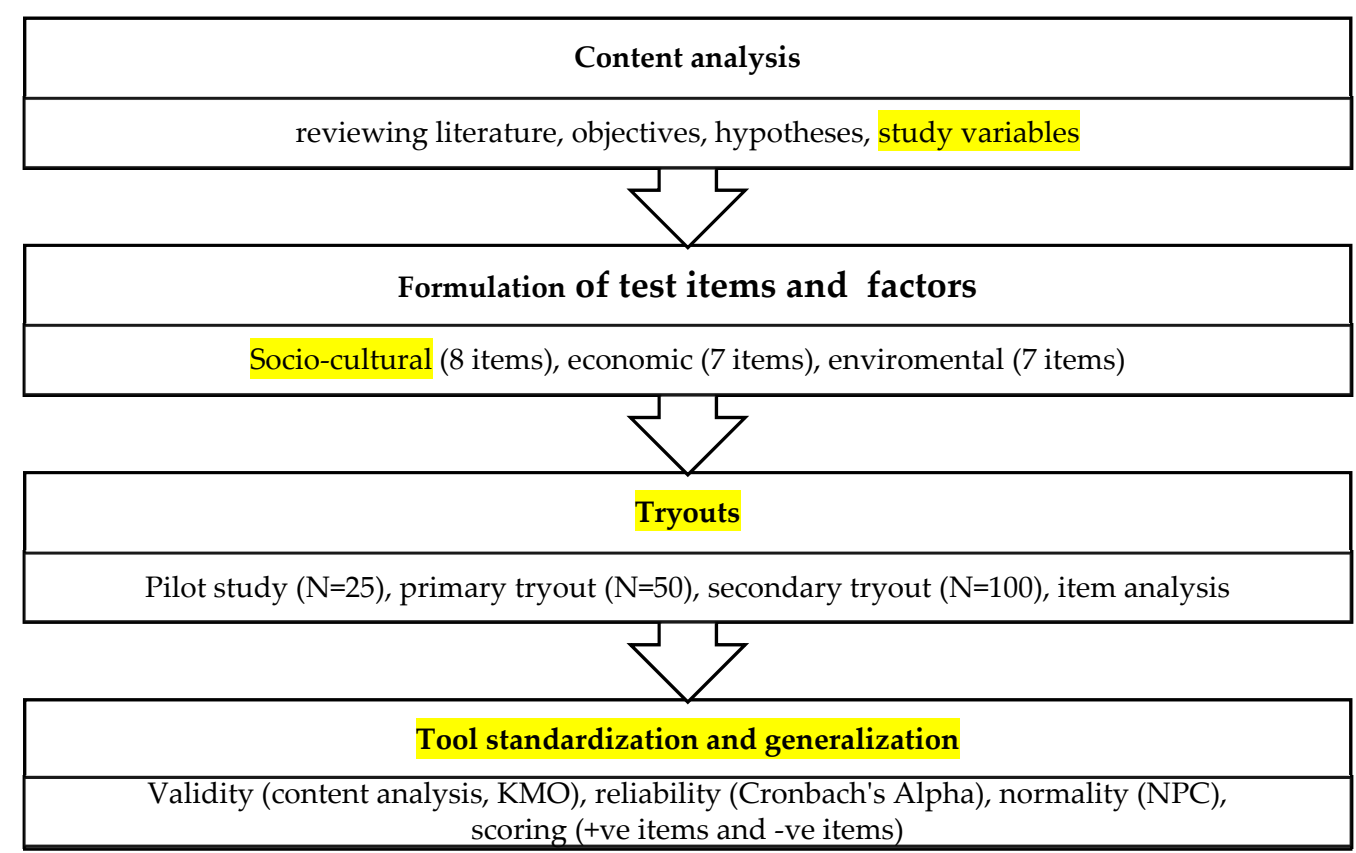

Figure 2. Literature search and tool construction.

According to the 2011 census conducted by the government of India, the population of Pushkar was 21,621. Out of this number, 200 were considered a sample that was an appropriate representation of the population and significant at 0.01 level of critical value and confidence interval under $\left(\mathrm{n}=\mathrm{N} \times \mathrm{X} /(\mathrm{X}+\mathrm{N}-1)\right.$, where, $\left.\mathrm{X}=\mathrm{Z} \alpha / 22^{*} p^{*}(1-p) / \mathrm{MOE} 2\right)$ formula [35].The required sample was collected through a simple random sampling technique. The selection process and selected sample of 200 respondents were in accordance with the recommendation given by [59] for performing advanced multivariate statistics, such as regression analysis and structural equation modeling (SEM).

Regression analysis $\left(\mathrm{H} 2\right.$ and $\left.\mathrm{O}_{2}\right)$ is a way of predicting future events between a dependent (socio-cultural, economic, and environmental development) and one or more independent variables (also known as predictors), i.e., sustainable tourism development. The main uses of regression analysis are forecasting, time series modeling, and finding the cause-effect relationship between variables.

Multivariate correlation coefficient and SEM $\left(\mathrm{H} 3\right.$ and $\left.\mathrm{O}_{3}\right)$ were used to investigate the relationship among socio-cultural, environmental, economic, and sustainable tourism development, and these relationships are explained by the SEM model in view of the consolidated effect on socio-cultural, environmental, and economic development on sustainable tourism development (Figure 3).

For constructing the Local Satisfaction Measure Scale (LSMS), similar previously constructed tools, such as Tourism Impact Attitude Scale (TIAS) by [60] and Sustainable Tourism Attitude Scale (SUS-TAS) by [61] were referred to. Present-scale LSMS has three elements: socio-cultural, economic, and environmental. As suggested by UNWTO, these are important, complete, and comprehensive elements when considering sustainable tourism development. 


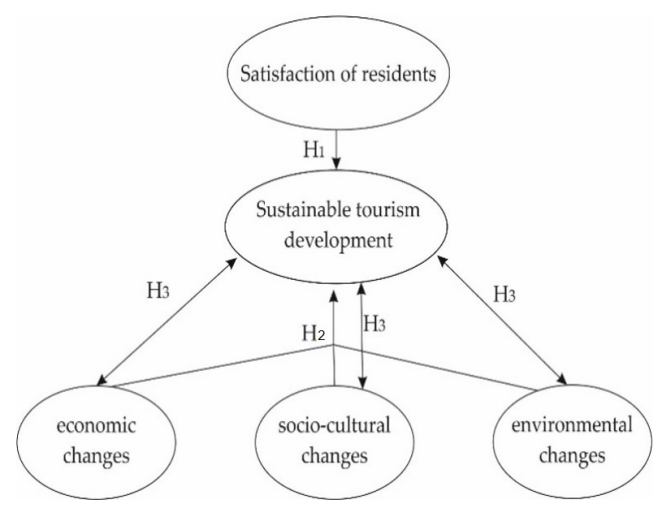

Figure 3. Conceptual and Analytical Framework.

While constructing the LSMS for creating a standardized tool, the steps followed included the construction of the tool and testing reliability, as well as the validation and normalization of the data [62]. A total of 22 items under 3 categories, i.e., economic impact ( 7 items), socio-cultural impact ( 8 items) and environmental impact ( 7 items) were considered (Appendix A).

First, content analysis, primary tryout (for the sample of 50 respondents), and expert opinions were taken. After making all the corrections based on the result of the primary tryout, a secondary tryout of LSMS was conducted on a sample of 100 respondents to perform item analysis and check the validity and reliability of the tool. For conducting the item analysis, two different methods were used: Method of Summated Ratings [57] was used for checking the differentiation power of each item in relation to others under overall tool testing, and each category went through a z-score and independent sample $t$-test. One sample $t$-test $\left(\mathrm{H} 1\right.$ and $\left.\mathrm{O}_{1}\right)$ was a univariate and parametric test used to determine satisfaction level of local residents about tourism development in the study area.

For measuring the relationship of each item with total items of the tool and individual items under each category, a correlation coefficient test was performed. After conducting both tests, it was found that all the selected items ( 22 in LSMS, 7 in economic impacts, 8 in socio-cultural impacts and 7 in environmental impacts) were specific and distinct from each other, and at the same time, all items were highly correlated with each other. For testing the validity of the LSMS tool, face validity, and content validity, the Kaiser-Meyer-Olkin (KMO) and Bartlett tests [63] were conducted. The values of the KMO test were 0.839, 0.782 , 0.811 , and 0.756 for overall tool, economic impacts, socio-cultural impacts, and environmental impacts, respectively, and these values were quite significant at 0.001 level of significance. Furthermore, the reliability of the Local Satisfaction Measurement Scale (LSMS) in each category and in the event of item deletion was tested through Cronbach's Alpha test; the values found were in the range of 0.737 to 0.882 and significant at 0.001 level of significance. After performing the required tests, such as item analysis, category analysis, validity, and reliability, it became clear that the constructed LSMS tool was a standardized form of the questionnaire and most appropriate for conducting the present study and achieving and testing its proposed objectives and hypotheses. After tool construction, more than 220 samples were collected from local residents who were $18+$ years of age. While editing, encoding, and scoring, it was found that few samples were incomplete; therefore, 200 samples were taken up for final analysis.

The data collected from 200 local residents were analyzed empirically and with the help of Statistical Package for Social Sciences (SPSS) 23.0 and Structural Equation Modeling Software (EQS) 6.1 software packages. All responses were recorded over a five-point Likert scale and a nominal scale manually and analyzed through the following tools: descriptive statistics, inferential statistics, confirmatory category analysis, regression analysis, and structural equation modeling (SEM). Before proceeding to the data analysis, the normality of data was also checked to decide whether to use parametric inferential statistics (if data were normally distributed over NPC) or non-parametric inferential statistics (if data were 
not normally distributed over NPC). For the present study, data collected were normally distributed, as the values of Skewness and Kurtosis were -0.217 and -0.130 , respectively, and these values fell within acceptable ranges of \pm 2 [64].

\section{Residents' Satisfaction toward Tourism Development in Pushkar-Survey Results}

The demographic information of local residents was recorded over nominal scale under the following variables: age, gender, marital status, education qualification, occupation, and income per month. After the analysis of demographic profiles of respondents, it was found that the highest number of respondents were from the 31 to 40 age group $(52 \%)$, male $(94.5 \%)$, married $(88 \%)$, private employees $(42 \%)$, and with an income between 25,001 Indian rupee (INR) to 50,000 INR (46\%). Demographic profiles of local residents show that most of them were young, less educated and mainly depended on tourism for their survival (Table 2).

Table 2. Demographic profile of local residents.

\begin{tabular}{|c|c|c|}
\hline Demographic Variable & Frequency & Percentage \\
\hline \multicolumn{3}{|c|}{ Age } \\
\hline Below 20 Years & 1 & 0.5 \\
\hline $21-30$ & 58 & 29 \\
\hline $31-40$ & 104 & 52 \\
\hline Above 40 Years & 37 & 18.5 \\
\hline \multicolumn{3}{|c|}{ Gender } \\
\hline Male & 189 & 94.5 \\
\hline Female & 11 & 5.5 \\
\hline \multicolumn{3}{|c|}{ Marital Status } \\
\hline Married & 176 & 88 \\
\hline Unmarried & 24 & 12 \\
\hline Any Other & 0 & 0 \\
\hline \multicolumn{3}{|c|}{ Education } \\
\hline Up to Secondary & 39 & 19.5 \\
\hline Higher Secondary & 87 & 43.5 \\
\hline Graduate & 64 & 32 \\
\hline Post Graduate & 10 & 05 \\
\hline Any Other & 0 & 0 \\
\hline \multicolumn{3}{|c|}{ Occupation } \\
\hline Student & 2 & 01 \\
\hline Government Employees & 32 & 16 \\
\hline Private Employees & 84 & 42 \\
\hline Businessmen & 68 & 34 \\
\hline Any Other & 14 & 07 \\
\hline \multicolumn{3}{|c|}{ Income per Month (INR) } \\
\hline Below 25,000 & 37 & 18.5 \\
\hline $25,001-50,000$ & 92 & 46 \\
\hline $50,001-75,000$ & 61 & 32 \\
\hline $75,001-100,000$ & 7 & 3.5 \\
\hline More Than 100,001 & 0 & 0 \\
\hline
\end{tabular}

Source: own elaboration, primary data.

Residents of any destination play an essential role in developing tourism in responsible and sustainable ways [64]. To measure the satisfaction level of residents of Pushkar toward 
sustainable tourism development and its core parameters (economic, socio-cultural, and environmental development), one-sample $t$-test was conducted, and the results were computed in Table 3. To perform a one-sample $t$-test, a hypothesized mean or test value is required; in the case of perception and satisfaction, the highest mean value for positive items and the lowest mean value for negative items are considered as test values/expected values [65-67], as each tourism personnel member has the highest level of perception and wants to have the fullest satisfaction [68-72]. Thus, for overall satisfaction, the test value was $110(22 \times 5=110)$, for environmental and economic satisfaction it was $35(7 \times 5=35)$, and for socio-cultural satisfaction it was $40(8 \times 5=40)$.

Table 3. Satisfaction level of local residents toward overall, economic, socio-cultural, and environmental development in Pushkar, India.

\begin{tabular}{cccccccc}
\hline Variable & $\mathbf{N}$ & $\begin{array}{c}\text { Hypothesize } \\
\text { Mean }\end{array}$ & Mean & S.D & $\begin{array}{c}\text { Mean } \\
\text { Difference }\end{array}$ & t-Ratio & $p$-Value \\
\hline Overall satisfaction of locals & 200 & 110 & 76.01 & 3.364 & 33.990 & 142.893 & $0.000^{* *}$ \\
\hline Economic satisfaction of locals & 200 & 35 & 27.71 & 1.671 & 7.295 & 61.743 & $0.000^{* *}$ \\
\hline Socio-cultural satisfaction of locals & 200 & 40 & 29.18 & 2.088 & 10.820 & 73.287 & $0.000^{* *}$ \\
\hline Environmental satisfaction of locals & 200 & 35 & 19.13 & 2.277 & 15.875 & 98.592 & $0.000^{* *}$ \\
\hline & $*^{* *}$ Significant at 0.01 level; Source: own study. & &
\end{tabular}

Table 3 shows residents' satisfaction level toward overall economic, socio-cultural, and environmental development due to tourism. Overall tourism development values of the sample mean, hypothesized mean (test value), and standard deviation were 76.01, 110 and 03.364, respectively, and a mean difference of 33.990 was calculated between the mean score of locals' satisfaction and the hypothesized mean of overall tourism development in Pushkar, India. Furthermore, with the help of t-value (142.893) and $p$-value $(0.000 * *)$, it was confirmed that the existing difference of 33.990 between the hypothesized mean (test value) of overall tourism development in the study area and residents' satisfaction toward overall tourism development was significant at 0.01 level of significance, as the value of $p$ was $0.000(p=0.000<0.01)$, which was less than 0.01 . However, in the case of responsible and sustainable tourism development, there should be an insignificant difference between the test value of overall tourism development and a sample mean of local residents' satisfaction [73], whereas tourism development in Pushkar, India, and local residents' satisfaction toward it had a significant gap.

For local residents' satisfaction toward economic impacts of tourism development in the Pushkar region of Rajasthan, the values of sample mean, hypothesized mean (test value), and standard deviation were $27.71,35$, and 1.671 , respectively. This shows the mean difference of 7.295 between the hypothesized mean of economic impacts of tourism and the sample mean of local residents' satisfaction toward it. Whether this difference was significant or not has been confirmed through values of $\mathrm{t}$-ratio and $p$, which were 61.743 and $0.000^{* *}$. As the value of $p$ was $0.000(p=0.000<0.01)$, which was less than 0.01 , there was a significant difference between the economic impacts of tourism and the satisfaction level of local residents about it. However, each tourism activity has economic impacts on a destination, and it benefits the local residents directly or indirectly [74]. Collectively, local residents were satisfied about the economic development of the region due to tourism, but they were not fully satisfied with each parameter of sustainability. While analyzing the data, it was found that local residents were satisfied with test items, such as job creation, increased prices of goods, services, land, and other amenities, infrastructure, etc., whereas they showed their dissent about test items related to personal income, equal distribution of money, market for indigenous Rajasthani products, economic support from the government and NGOs, and overall economic development of the region and local communities. A complete and comprehensive economic development for local residents without any negative impact is most important in sustainable tourism development [75]. 
Satisfaction level of local residents toward socio-cultural impacts of tourism development in Pushkar was measured through one-sample $t$-test, where the values of the sample mean, hypothesized mean (test value), and standard deviation were $29.18,40$, and 2.088 , respectively, and the mean difference of 10.820 was found between socio-cultural impacts of tourism and local residents' satisfaction toward this. Values of the t-ratio and $p$ were also calculated in order to check whether existing difference was significant or not. The values of t-ratio and $p$ were 73.287 and $0.000^{* *}$. Here, the value of $p$ was 0.000 ( $p=0.000<0.01$, which was less than 0.01 ; therefore, the existing difference of 10.820 was significant at 0.01 level of significance between socio-cultural impacts of tourism and satisfaction level of local residents about it. The socio-cultural aspect of any community is a very sensitive phenomenon and can easily have a negative impact if it is not taken care of through responsibility and sustainability [76].

While conducting the interviews with local residents, it emerged that they were mainly facing socio-cultural problems, such as cultural clashes, demonstration effects, drug abuse, ethnocentrism, rape, alcoholism, devastation of indigenous culture, cuisine, heritage, art, artefacts, products, and services. Because of these negative socio-cultural impacts of tourism, local residents were not satisfied with present tourism development in the region and not sure about the future either. Positive socio-cultural impacts of tourism are crucial and vital for rejuvenating and developing responsible and sustainable tourism, and this has been well documented by several authors [77-81].

The environmental impacts of tourism were also measured through satisfaction level of local residents in the study area, where the value of the sample mean, hypothesized mean, and standard deviation were 19.13, 35, and 2.277, respectively, and a mean difference of 15.875 was found between environmental impacts of tourism and local residents satisfaction toward it. Furthermore, with the help of t-ratio (98.592) and $p$-value $\left(0.000^{* *}\right)$, it was confirmed that the existing difference between local satisfaction and environmental impacts of tourism was significant at 0.01 level of significance, as the value of $p$ was 0.000 $(p=0.000<0.01)$, which was less than 0.01. From the residents' viewpoint, Pushkar has been facing several environmental issues, such as pollution, loss of natural vegetation and landscape, degradation of the natural environment, Ghats, lake, and temples, congestion, and noise. Local residents believe that all of these have been a result of irresponsible and unsustainable tourism practices followed by the tourists, local residents, and stakeholders and that no strategic and comprehensive planning and guidelines as such have been followed by the local and state governments. Local residents' level of satisfaction toward environmental impacts of tourism is important for sustainable tourism development at any destination [27].

Figure 4 shows that local residents had high satisfaction with overall, economic, and socio-cultural tourism development in Pushkar, whereas they had average satisfaction with environmental development.

\subsection{Impacts of Socio-Cultural, Economic, and Environmental Development on Sustainable Tourism Development}

The socio-cultural, economic, and environmental development collectively impacts and leads to responsible and sustainable tourism development [82]. In order to measure the impacts of socio-cultural, economic, and environmental development in Pushkar, India on sustainable tourism development, a test $\mathrm{H} 2$, multiple regression analyses among sociocultural development (IV), economic development (IV), environmental development (IV), and sustainable tourism development (DV) were performed. 


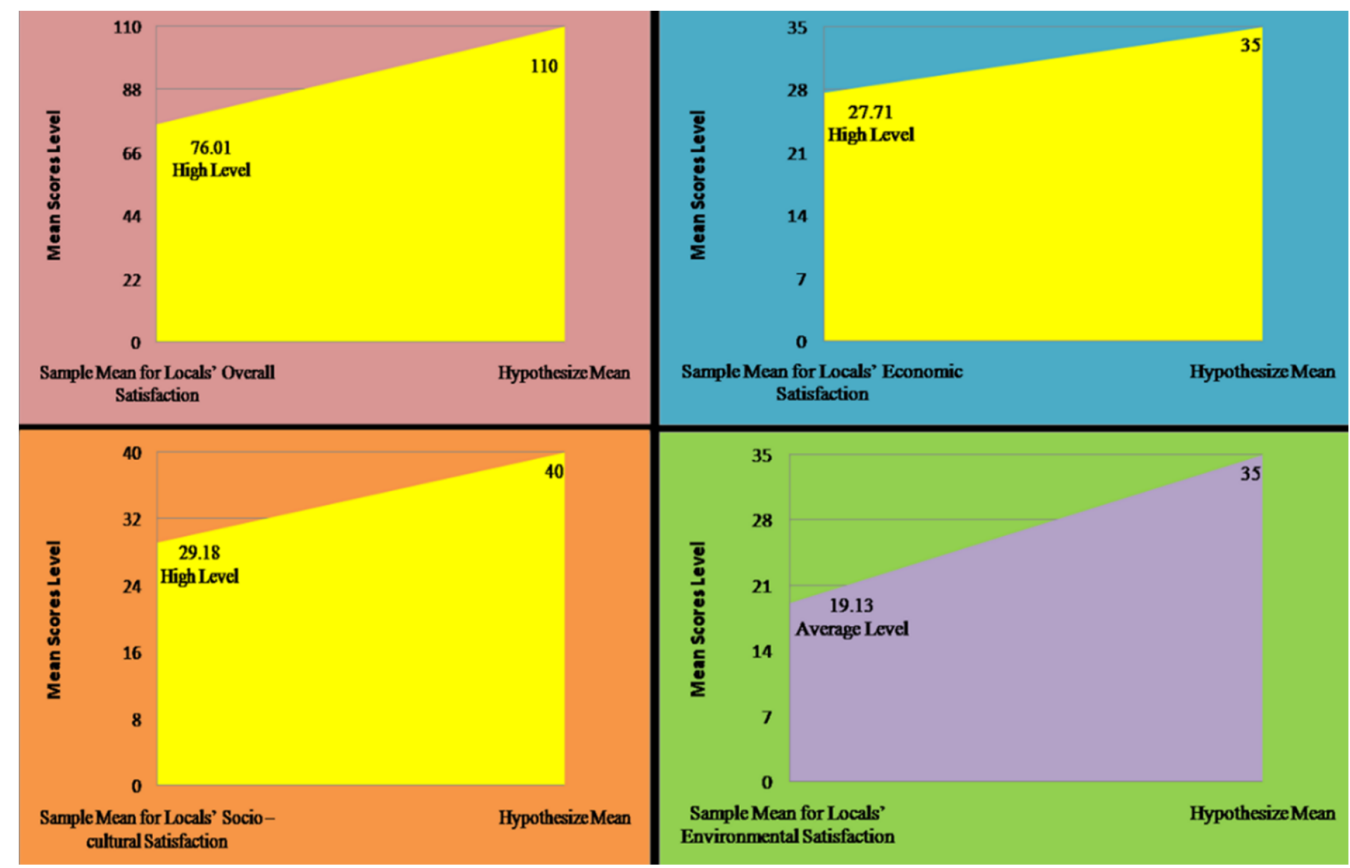

Figure 4. Satisfaction of residents toward overall, economic, socio-cultural, and environmental impacts of tourism in Pushkar, India.

Table 4 measured the impacts of socio-cultural, environmental, and economic development on sustainable tourism development individually and collectively through regression analysis, taking sustainable tourism development as a dependent variable (DV), and socio-cultural, environmental, and economic development as independent variables (IV). The values of correlation coefficient " $\mathrm{R}$ " and $p$-ratio between sustainable tourism development (DV) and socio-cultural development (IV) of 0.998 and $0.000 * *(0.000<0.01)$, respectively, show that there was a high positive correlation between sustainable tourism development and socio-cultural development. Furthermore, the extent of variability in sustainable tourism development due to socio-cultural development was confirmed through the coefficient of determination $\mathrm{R}^{2}$ that was 0.996 and the share of independent variable (socio-cultural development) which was $99 \%$. It means that socio-cultural development accounts for $99 \%$ in total sustainable and responsible tourism development. Positive sociocultural development is an important parameter for sustainable tourism development at any destination, and it is also associated with other indicators of sustainability [83].

Table 4. Socio-cultural, economic, and environmental development (independent variable) and sustainable tourism development (dependent variable) in Pushkar.

\begin{tabular}{|c|c|c|c|c|c|}
\hline Variable & $\mathbf{R}$ & $\mathbf{R}^{2}$ & $\begin{array}{c}\text { Share of Independent } \\
\text { Variable }(\%)\end{array}$ & $\begin{array}{c}\text { Dispersion of } \\
\text { Regression Line }\end{array}$ & $p$-Value \\
\hline Sustainable Tourism Development (DV) & Constant & \multirow{2}{*}{0.996} & \multirow{2}{*}{$99 \%$} & \multirow{2}{*}{0.529} & \multirow{2}{*}{$0.000^{* *}$} \\
\hline Socio-Cultural Development (IV) & 0.998 & & & & \\
\hline Sustainable Tourism Development (DV) & Constant & \multirow{3}{*}{1.00} & \multirow{3}{*}{$100 \%$} & \multirow{3}{*}{0.101} & \multirow{3}{*}{$0.000 * *$} \\
\hline Socio-Cultural Development (IV) & 0.835 & & & & \\
\hline Environmental Development (IV) & 0.175 & & & & \\
\hline Sustainable Tourism Development (DV) & Constant & \multirow{4}{*}{1.00} & \multirow{4}{*}{$100 \%$} & \multirow{4}{*}{0.046} & \multirow{4}{*}{$0.000 * *$} \\
\hline Socio-Cultural Development (IV) & 0.316 & & & & \\
\hline Environmental Development (IV) & 0.250 & & & & \\
\hline Economic Development (IV) & 0.450 & & & & \\
\hline
\end{tabular}

** Significant at 0.01 level; Source: own elaboration. 
For measuring the impacts of socio-cultural (IV) and environmental development (IV) collectively on sustainable tourism development (DV), the values of correlation coefficient $\mathrm{R}$ were 0.835 and 0.175 with socio-cultural and environmental development, respectively. The value of $p$-ratio was $0.000 * *(0.000<0.01)$ for both. Furthermore, the value of the coefficient of determination $\mathrm{R}^{2}$ was $1.00(0.835+0.175)$, which shows the extent of variability in the dependent variable (sustainable tourism development) because of independent variables (socio-cultural development and environmental development). With the help of obtained values of the correlation coefficient " $R$ " and the coefficient of determination $\mathrm{R} 2$, it is concluded that there was a positive correlation between sustainable tourism development (DV) and socio-cultural development (IV) and environmental development (IV), and the share of both socio-cultural development and environmental development in development of sustainable tourism was 100\% at the Pushkar region of Rajasthan, India (Table 5). Understanding local residents' satisfaction toward socio-cultural and environmental development can minimize their negative impacts and contribute to sustainable tourism development [84].

Table 5. Regression model for socio-cultural, environmental, and economic development and sustainable tourism development.

\begin{tabular}{ccc}
\hline Model & $\begin{array}{c}\text { Standardized Coefficient } \\
\text { (Beta) }\end{array}$ & $p$-Value \\
\hline Constant (DV) & 73.203 & $0.000^{* *}$ \\
\hline Socio-Cultural Development (IV) & 0.998 & $0.000^{* *}$ \\
\hline Constant (DV) & 72.867 & $0.000^{* *}$ \\
\hline Socio-Cultural Development (IV) & 0.835 & $0.000^{* *}$ \\
\hline Environmental Development (IV) & 0.175 & $0.000^{* *}$ \\
\hline Constant (DV) & 71.485 & $0.000^{* *}$ \\
\hline Socio-Cultural Development (IV) & 0.316 & $0.000^{* *}$ \\
\hline Environmental Development (IV) & 0.250 & $0.000^{* *}$ \\
\hline Economic Development (IV) & 0.450 & $0.000^{* *}$ \\
\hline ** Significant at 0.01 level; Source: own elaboration. & &
\end{tabular}

With regard to the impact of all three parameters of sustainability, i.e., socio-cultural (IV), environmental (IV), and economic development (IV) on sustainable tourism development (DV), the values of the correlation coefficient $R$ were $0.316,0.250$, and 0.450 for socio-cultural (IV), environmental (IV), and economic development (IV), respectively. The value of $p$-ratio was $0.000 * *(0.000<0.01)$ for all three indicators of sustainability. Furthermore, the value of the coefficient of determination R2, i.e., $1.00(0.316+0.250+0.450)$, showed the extent of variability in a dependent variable (sustainable tourism development) because of independent variables (socio-cultural development, environmental development, and economic development). With the help of obtained values of the correlation coefficient $R(0.316,0.250$ and 0.450 for socio-cultural, environmental, and economic development) and the coefficient of determination $\mathrm{R} 21.00(0.316+0.250+0.450)$, it can be concluded that there was positive correlation between sustainable tourism development (DV) and socio-cultural development (IV), environmental development (IV), and economic development (IV), and the share of all three in the overall development of responsible and sustainable tourism development in Pushkar was 100\%. It is quite clear from the results above that socio-cultural, environmental, and economic developments are related to core components of sustainable tourism development, as also suggested in the study conducted [85].

Moreover, whether socio-cultural, environmental, and economic developments individually and collectively have a significant impact on sustainable tourism development 
or not was checked with the help of regression equations, and the results are presented in Table 5.

With the help of the above-computed regression analysis in Table 5, the following regression equations were formulated concerning the impacts of socio-cultural development (IV), environmental development (IV), and economic development (IV) on sustainable tourism development (DV) in Pushkar.

$$
Y=\alpha 0+\alpha 1(X 1)
$$

Sustainable Tourism Development $=\alpha 0+\alpha 1$ (Socio-Cultural Development)

Sustainable Tourism Development $=73.203+0.998$ (Socio-Cultural Development)

$$
Y=\alpha 0+\alpha 1(X 1)+\alpha 2(X 2)
$$

Sustainable Tourism Development $=\alpha 0+\alpha 1$ (Socio-Cultural Development $)+\alpha 2($ Environmental Development $)$

Sustainable Tourism Development $=72.867+0.835$ (Socio-Cultural development $)+0.175$ (Environmental Development)

$$
Y=\alpha 0+\alpha 1(X 1)+\alpha 2(X 2)+\alpha 3(X 3)
$$

Sustainable Tourism Development $=\alpha 0+\alpha 1$ (Socio-Cultural Development $)+\alpha 2($ Environmental Development $)+\alpha 3$ (Economic Development)

$\begin{aligned} \text { Sustainable Tourism Development }= & 71.485 \\ + & 0.316(\text { Socio-Cultural Development })+0.250(\text { Environmental Development }) \\ & +0.450(\text { Economic Development })\end{aligned}$

As per Table 5 and the above equations, dependent variables (sustainable tourism development) of $73.203,72.876$, and 71.485 were found with the scores of independent variables (socio-cultural development, socio-cultural and environmental development, socio-cultural, environmental, and economic development) $0.998,0.835+0.175$ and $0.316+0.250+0.450$, respectively. It means that if the values of independent variables (socio-cultural development, socio-cultural and environmental development, socio-cultural, environmental, and economic development) are increased by one, then scores $(73.203,72.876$, and 71.485$)$ of the dependent variable (sustainable tourism development) are enhanced by $0.998,0.835+0.175$, and $0.316+0.250+0.450$, respectively. Moreover, for all three cases above, the value of $p$-ratio was $0.000(0.000<0.01)$, which was significant at 0.01 level of significance.

\subsection{Relationship among Socio-Cultural, Environmental, Economic, and Sustainable Tourism Development}

The effective and positive relationship among socio-cultural, environmental, and economic development strongly impacts responsible and sustainable tourism development [86]. As seen before, each one of them (socio-cultural, environmental and economic development) is equally and significantly important for sustainable tourism development, and each one of them individually and collectively must also have positive and effective relationship. To measure this relationship among socio-cultural, environmental, and economic development and test $\mathrm{H} 3$, structural equation modeling (SEM) was performed through the EQS 6.1 application, and the results were computed in Table 6.

Table 6. Relationship among socio-cultural, environmental, economic, and sustainable tourism development.

\begin{tabular}{ccccc}
\hline Variable & $\begin{array}{c}\text { Socio-Cultural } \\
\text { Development }\end{array}$ & $\begin{array}{c}\text { Environmental } \\
\text { Development }\end{array}$ & $\begin{array}{c}\text { Economic } \\
\text { Development }\end{array}$ & $\begin{array}{c}\text { Sustainable Tourism } \\
\text { Development }\end{array}$ \\
\hline Socio-Cultural Development & 1.00 & $0.998^{* *}$ & $0.930^{* *}$ & $0.998^{* *}$ \\
\hline Environmental Development & & 1.00 & $0.906^{* *}$ & $0.992^{* *}$ \\
\hline Economic Development & & & 1.00 & $0.952^{* *}$ \\
\hline $\begin{array}{c}\text { Sustainable Tourism } \\
\text { Development }\end{array}$ & & & 1.00 \\
\hline
\end{tabular}

** Significant at 0.01 level. 
Table 6 shows the relationships among socio-cultural, environmental, economic, and sustainable tourism developments with the help of structural equation modeling (SEM) in which the Pearson correlation coefficient $r$ was calculated among socio-cultural, environmental, economic, and sustainable tourism developments.

The values of the correlation coefficient between socio-cultural development and environmental development, economic development and sustainable tourism development was $0.998,0.930$ and 0.998 , respectively. This means that socio-cultural development had a high positive relationship with environmental development, economic development, and sustainable tourism development $( \pm 0.9- \pm 1.0=$ very high correlation). Similarly, the values of the correlation coefficient between environmental development and economic development and sustainable tourism development was 0.906 and 0.992, respectively, which indicates that environmental development had a high positive relationship with economic development and sustainable tourism development $( \pm 0.9- \pm 1.0=$ very high correlation). Furthermore, the correlation coefficient values between economic development and sustainable tourism development were 0.952, indicating that economic development had a high positive relationship with sustainable tourism development $( \pm 0.9- \pm 1.0=$ very high correlation).

The regression and structural equation modeling (SEM) analysis results conclude that socio-cultural, environmental, and economic development had perfect positive relationships among themselves, and that they impacted responsible and sustainable tourism development in the study area. It is also well established that socio-cultural, environmental, and economic developments are core parameters of responsible and sustainable tourism development, as suggested by various studies conducted $[86,87]$.

The SEM model in Figure 5 clearly shows the positive relationship of various parameters of sustainable tourism development, such as socio-cultural, economic, and environmental development among each other and with sustainable tourism development. Whenever socio-cultural development takes place at the destination, environmental, economic, and sustainable tourism automatically accelerates by $99 \%, 93 \%$, and 99\%, respectively, and vice versa. Similarly, when environmental development occurs, economic and sustainable development increases by $90 \%$ and $99 \%$, respectively, and vice versa. If economic development takes place, then sustainable tourism development increases by $95 \%$. Moreover, it is clear from the model that sustainable tourism development depends on socio-cultural and environmental development, followed by economic development, as explained [87]. A simple allocation of funds ensures economic development cannot lead to sustainable tourism development.

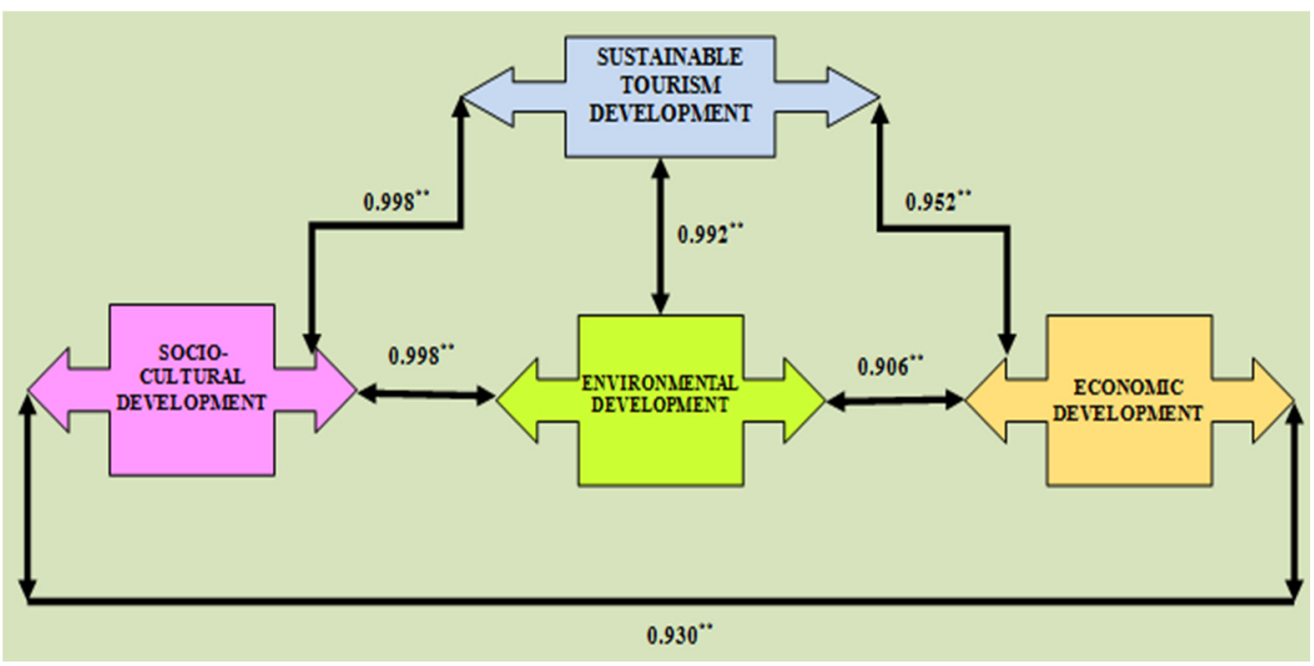

Figure 5. The SEM model final output. ${ }^{* *}$ significant at 0.01 level of significance. 


\section{Conclusions and Recommendations}

The research results present a complex picture of the relationships between sustainable tourism development and socio-cultural, economic, and environmental development. The latter plays the greatest role in the satisfaction of local residents. In order to achieve the set objectives of the study, hypotheses were formulated and verified: H1: "Local residents will have high level of satisfaction toward sustainable tourism development in the Pushkar region of Rajasthan." This has been rejected, with 0.01 level of significance and its corresponding objective "to measure the satisfaction level of local residents toward sustainable tourism development in the Pushkar region of Rajasthan" has been explained. Local residents of Pushkar are not satisfied with the overall tourism development in the area in terms of sustainability. There could be multiple reasons for local residents' dissatisfaction toward overall tourism development in Pushkar, such as existing government policies, infrastructure development, employment opportunities for local people, preservation and conversation of local culture, cuisine, and dance forms, heritage, Ghats, and temples, protection of ecology and environment, and many more. Policies and planning pertaining to tourism development at any destination should be based on the interests of local communities [88].

Individually and collectively, socio-cultural, environmental, and economic developments will determine the level of sustainable tourism development. Thus, the proposed null hypothesis H2-"socio-cultural, economic, and environmental developments have no significant impact on sustainable tourism" - is rejected, and its corresponding objective "to measure the impact of socio-cultural, economic, and environmental development on sustainable tourism development" has been explained. Socio-cultural, economic, and environmental developments have a significant impact on sustainable tourism development. Without positive socio-cultural, environmental, and economic development over the destinations, responsible and sustainable tourism cannot be developed [89-91]. There was a positive correlation between sustainable tourism development (DV) and socio-cultural development (IV), environmental development (IV), and economic development (IV), and the share of all three (socio-cultural development, environmental development, and economic development) was $100 \%$ in the overall development of responsible and sustainable tourism development in Pushkar. The proposed hypothesis H3 - "socio-cultural, economic, environmental, and sustainable tourism developments have positive relationships" -is accepted, and its corresponding objective "to understand the relationships among socio-cultural, environmental, economic, and sustainable tourism developments" has been explained.

The results of the present study reveal that local residents of Pushkar have different level of satisfaction toward socio-cultural development, environmental development, economic development, and overall sustainable tourism development. They have higher level of satisfaction with economic development, followed by socio-cultural and environmental development. There is a significant gap between local residents' satisfaction and sociocultural, environmental, economic, and overall tourism development in the study area. It is not a good sign for sustainable tourism development in the region [92,93]. Furthermore, the findings of the study suggest that sustainable tourism development is significantly impacted through socio-cultural, environmental, and economic developments, as the beta values of regression equations for socio-cultural development, socio-cultural and environmental development and socio-cultural development, environmental development and economic development were $0.998,1.00(0.835+0.175)$ and $1.00(0.316+0.250+0.450)$, respectively.

In order to develop tourism in sustainable ways, there should be an equal and appropriate development of socio-cultural, environmental, and economic aspects of a destination $[90,94]$. From the output of structural equation modeling (SEM), it is concluded that there is a perfect positive correlation among socio-cultural, environmental, economic, and sustainable tourism developments, as the value of the correlation coefficient " $R$ " was above 0.9 in all cases. If development of any parameter of sustainability, such as socio-cultural, environmental, and economic, is increased, it also ensures development of other parameters of sustainability and vice versa. 
On the basis of the findings of the present study, various recommendations are made to the state government, Rajasthan Tourism Development Cooperation, tourism stakeholders, local residents, and tourism planners of Pushkar tourism. It is important to reduce the negative socio-cultural impacts, such as cultural clashes, demonstration effect, drug abuse, racism, crime, robberies, prostitution, cheating on tourists, and rapes; negative environmental impacts, such as congestion, pollution, noise, degradation of natural resources, temple, Ghats, lake, waste and sewage problems, carrying capacity problems, shortage of drinking water, and ecological disturbances; and negative economic impacts, such as overdependency on tourism, lack of employment for local people, and the import of foreign tourism products, especially during the time of the Pushkar Fair. Over the years, these negative impacts have been quite visible, causing serious problems for sustainable tourism development. In order to minimize all the negative impacts, local residents, stakeholders, RTDC, and the Pushkar tourism board need to work collectively toward development and promotion of responsible and sustainable tourism.

Tourism organizations working in Pushkar, such as RTDC (Rajasthan Tourism Development Corporation), RSHCL (Rajasthan State Hotel Corporation Limited), DoT (Department of Tourism), TIBs (Tourist Information Bureaus), and RITTMAN (Rajasthan Institute of Tourism and Travel Management) must play an active role in planning and managing tourism development sustainably. It is also equally important to ensure active participation and support of local bodies, such as RAJSICO (Rajasthan Small Industries Corporation), DRDA (District Rural Development Agency), AVS (Avas Vikas Sansthan), DC (District Collectorates), Municipal Councils, Municipal Corporations, and Gram Panchayats, as these are legitimate stakeholders at the destination and can play an important role toward management and development of sustainable tourism. All the stakeholders of tourism at Pushkar must work toward a common vision and direction, maintain carrying capacity, especially at the time of the Pushkar Fair, promote indigenous products, culture, heritage, and handicraft of Rajasthan, as well as strategic and scientific planning for sustainable tourism development and increasing the number of cattle during the festival (mainly camels, as their numbers keep decreasing year by year). Due to the COVID-19 pandemic, it is also a big challenge to revive the tourism and Camel Fair in the region and ensure and develop tourism responsibly and sustainably.

There are some limitations in this study. First, the study focused on a relatively small sample of residents. Second, most of the completed questionnaires were collected during the fair, which could have influenced the respondents' answers. Other dimensions on scales could also have been used.

This study contributes to tourism literature by developing a coherent, comprehensive, and comparative understanding of the role of residents' satisfaction in the impact of tourism on economic, socio-cultural, and environmental changes. Researchers are discussing the development of coherent tools to study the effect of tourism on the local population [95-98]. Over a period of time, expectations of tourists and local residents about tourism development has been changing from general to specific, in accordance with their needs, wants, and derides [99]; therefore, it is important to ensure active participation of local residents and tourist feedback while designing and developing tourism policies and guidelines for the destinations [100].

The presented locals satisfaction measure scale can be used to measure residents' satisfaction toward tourism development in other places. Local satisfaction measurement scale (LSMS) and structural equation modeling (SEM) used in the present study could also be applicable in future research related to perception and satisfaction of residents toward tourism development under core indicator of sustainability. Depending on the conditions, the developed LSMS tool may be modified to adapt it to the specific needs of research on the satisfaction of the local community. However, present research work is limited to residents' satisfaction toward socio-cultural, economic, and environmental development of Pushkar as a sustainable tourism destination and does not include tourists, service providers, and stakeholders. 
Author Contributions: This study has been designed and conducted by all of the authors collectively and comprehensively. The introduction, literature review, research design, methodology, tool construction, data collection, analysis, and conclusions were written and performed by S.T.; N.T.-P.; S.K.G. and M.P.S. All authors have read and agreed to the published version of the manuscript.

Funding: The publication was funded by the Research Excellence Initiative program of the University of Silesia in Katowice, Poland.

Acknowledgments: We thank local residents, stakeholders, and the tourism board of Pushkar, Rajasthan, for their active participation, valuable time and contribution. We also acknowledge and thank for the valuable input of our fellow research colleagues and professors.

Conflicts of Interest: The authors declare no conflict of interest.

\section{Appendix A}

Table A1. Economic Impact.

\begin{tabular}{|c|c|c|c|c|c|c|}
\hline S.No. & Statements & SD & D & $\mathbf{N}$ & A & SA \\
\hline 1. & Tourism has provided jobs for your local community & 1 & 2 & 3 & 4 & 5 \\
\hline 2. & Prices of goods and services have increased due to tourism development & 5 & 4 & 3 & 2 & 1 \\
\hline 3. & The personal income of local residents has increased due to tourism development & 1 & 2 & 3 & 4 & 5 \\
\hline 4. & Tourism development improves the quality of local services & 1 & 2 & 3 & 4 & 5 \\
\hline 5. & Tourism creates new markets for the local products and services & 1 & 2 & 3 & 4 & 5 \\
\hline 6. & Tourism development has increased the number of local entrepreneurs & 1 & 2 & 3 & 4 & 5 \\
\hline 7. & There is an improvement of roads and other public services due to tourism development & 1 & 2 & 3 & 4 & 5 \\
\hline
\end{tabular}

Table A2. Socio-Cultural Impacts.

\begin{tabular}{|c|c|c|c|c|c|c|}
\hline S.No. & Statements & SD & $\mathbf{D}$ & $\mathbf{N}$ & A & SA \\
\hline 1. & $\begin{array}{l}\text { Tourism encourages varieties of socio-cultural activities performed by locals, e.g., arts, } \\
\text { music, prayers, fair and festival etc. }\end{array}$ & 1 & 2 & 3 & 4 & 5 \\
\hline 2. & Tourism has increased local awareness and recognition of the local culture and heritage & 1 & 2 & 3 & 4 & 5 \\
\hline 3. & Tourism has provided opportunities to conserve and preserve local art, culture and heritage & 1 & 2 & 3 & 4 & 5 \\
\hline 4. & Provides opportunities for acculturation & 1 & 2 & 3 & 4 & 5 \\
\hline 5. & Living standard of locals has increased because of tourism development & 1 & 2 & 3 & 4 & 5 \\
\hline 6. & Tourism has changed the traditional culture and social norms & 5 & 4 & 3 & 2 & 1 \\
\hline 7. & Tourism makes you feel insecure about your future & 5 & 4 & 3 & 2 & 1 \\
\hline 8. & Do you think tourists exaggerate problem of social abuse like drugs, prostitution, alcoholism & 5 & 4 & 3 & 2 & 1 \\
\hline
\end{tabular}

Table A3. Environmental Impact.

\begin{tabular}{|c|c|c|c|c|c|c|}
\hline S.No. & Statements & SD & $\mathbf{D}$ & $\mathbf{N}$ & A & SA \\
\hline 1. & Tourism development leads to urbanization & 1 & 2 & 3 & 4 & 5 \\
\hline 2. & Tourism development has resulted traffic congestion and crowd in the town & 5 & 4 & 3 & 2 & 1 \\
\hline 3. & Tourism developments strengthen efforts for environmental conservation & 1 & 2 & 3 & 4 & 5 \\
\hline 4. & $\begin{array}{l}\text { Proper tourism development is required that Ghats, lake and natural habitats be protected } \\
\text { at all times }\end{array}$ & 1 & 2 & 3 & 4 & 5 \\
\hline 5. & Construction of hotels \& tourist facilities has destroyed the natural environment & 5 & 4 & 3 & 2 & 1 \\
\hline 6. & Tourism facilities, amenities and ancillary service is cause irritation to the local communities & 5 & 4 & 3 & 2 & 1 \\
\hline 7. & $\begin{array}{l}\text { Tourism has a negative impact on the environment through disproportionate pollution and } \\
\text { damage to natural resources }\end{array}$ & 5 & 4 & 3 & 2 & 1 \\
\hline
\end{tabular}




\section{References}

1. WTTC World Travel and Tourism Council. 2020. Available online: https://www.wttc.org/about/media-centre/pressreleases/press-releases /2020/latest-research-fromwttc-shows-an-increase-in-jobs-at-risk-in-travel-and-tourism (accessed on 6 April 2020).

2. Cohen, E. The impact of tourism on the physical environment. Ann. Tour. Res. 1978, 5, 215-237. [CrossRef]

3. Butler, R. The concept of a tourist area cycle of evolution: Implications for management of resources. Can. Geogr. 1980, 24, 5-12. [CrossRef]

4. Christensen, A.M.; Beckmann, S. Consumers' Perspectives on Tourism and the Environment; Copenhagen Business School, Department of Marketing: Copenhagen, Denmark, 1998; pp. 7-12.

5. Gössling, S. Global environmental consequences of tourism. Glob. Environ. Chang. 2002, 12, 283-302. [CrossRef]

6. Sheldon, P.; Knox, J.M.; Lowry, K. Sustainability in a mature mass tourism destination: The case of Hawaii. Tour. Rev. Int. 2005, 9 , 47-59. [CrossRef]

7. Warnken, J.; Bradley, M.; Guilding, C. Exploring methods and practicalities of conducting sector-wide energy consumption accounting in the tourism accommodation industry. Ecolog. Econ. 2004, 48, 125-141. [CrossRef]

8. Cronk, Q. Islands: Stability, diversity, conservation. Biodivers. Conserv. 1997, 6, 477-493. [CrossRef]

9. Wen, J. Evaluation of tourism and tourist resources in China: Existing methods and their limitations. Int. J. Soc. Econ. 1998, 25, 467-485. [CrossRef]

10. Ahn, B.Y.; Lee, B.K.; Shafer, C.S. Operationalizing sustainability in regional tourism planning: An application of the limits of acceptable change framework. Tour. Manag. 2002, 23, 1-15. [CrossRef]

11. Álvarez, L.; Martín, A.; Casielles, R. Relationship Marketing and Information and Communication Technologies: Analysis of Retail Travel Agencies. J. Travel Res. 2007, 45, 453-463. [CrossRef]

12. Mortz, D.; Ray, C.; Jain, R. Major environmental problems facing the Hawaiian Islands: Management, policy, and technology transfer options. Int. J. Techn. Transf. Commerc. 2005, 4, 79-104. [CrossRef]

13. Jamal, T.B.; Getz, D. Collaboration theory and community tourism planning. Ann. Tour.Res. 1995, 22, 186-204. [CrossRef]

14. Cavus, S.; Tanrisevdi, A. Residents' attitudes toward tourism development: A case study in Kusadasi, Turkey. Tour. Anal. 2003, 7, 259-269. [CrossRef]

15. Liu, J.; Var, T. Resident attitudes toward tourism impacts in Hawaii. Ann. Tour. Res. 1986, 13, 193-214. [CrossRef]

16. Gössling, S. The consequences of tourism for sustainable water use on a tropical island: Zanzibar, Tanzania. J. Environ. Manag. 2001, 61, 179-191. [CrossRef]

17. Klasner, F.; Mikami, C. Land Use on the Island of O'ahu, Hawai'I; USGS: Reston, WV, USA, 1998.

18. Oki, D.; Brasher, A. Environmental Setting and the Effects of Natural and Human-Related Factors on Water Quality and Aquatic Biota, O'ahu, Hawai'I; USGS Water-Resources Investigations Report 03-4156; USGS: Reston, WV, USA, 2003.

19. Kumar, S.K.; Sunil, T. A system dynamics approach for tourism destinations waste and environmental management as an integral part of sustainable tourism development. J. Emerg. Techn. Innov. Res. 2019, 6, 194-198.

20. DBEDT 2006, County Population Facts. Available online: http://www.hawaii.gov/dbedt/info/census/population-estimate (accessed on 17 August 2021).

21. Bramwell, B. Actors, power, and discourses of growth limits. Ann. Tour. Res. 2006, 33, 957-978. [CrossRef]

22. Twining-Ward, L.; Butler, R. Implementing STD on a Small Island: Development and Use of Sustainable Tourism Development Indicators in Samoa. J. Sust. Tour. 2002, 10, 363-387. [CrossRef]

23. Dyer, P.; Gursoy, D.; Sharma, B.; Carter, J. Structural modeling of resident perceptions of tourism and associated development on the Sunshine Coast, Australia. Tour. Man. 2007, 28, 409-422. [CrossRef]

24. Hjalager, A.M. Tourism and the Environment: The Innovation Connection. J. Sust. Tour. 1996, 4, 201-218. [CrossRef]

25. Batra, G.; Kaur, N. New vistas in reducing the conflicts between tourism and the environment: An environmental audit approach. Manag. Audit. J. 1996, 11, 3-10. [CrossRef]

26. Hatipoglu, B.; Alvarez, M.D.; Ertuna, B. Barriers to stakeholder involvement in the planning of sustainable tourism: The case of the Thrace region in Turkey. J. Clean. Prod. 2016, 111, 306-317. [CrossRef]

27. He, P.; He, Y.; Xu, F. Evolutionary analysis of sustainable tourism. Ann. Tour. Res. 2018, 69, 76-89. [CrossRef]

28. Zolfani, S.H.; Sedaghat, M.; Maknoon, R.; Zavadskas, E.K. Sustainable tourism: A comprehensive literature review on frameworks and applications. Econ. Res. Ekon. 2015, 28, 171479.

29. Cui, L.; Wu, K.J.; Tseng, M.L. Selecting a remanufacturing quality strategy based on consumer preferences. J. Clean. Prod. 2017, 161, 1308-1316. [CrossRef]

30. Rusu, M. Eco-innovation and its contribution to sustainable development and competitiveness. Netw. Intell. Stud. 2013, 1, 127-135.

31. Tseng, M.L.; Bui, T.D. Identifying eco-innovation in industrial symbiosis under linguistic preferences: A novel hierarchical approach. J. Clean. Prod. 2017, 140, 1376-1389. [CrossRef]

32. Faulkner, B.; Tideswell, C. A Framework for Monitoring Community Impacts of Tourism. J. Sust. Tour. 1997, 5, 3-28. [CrossRef]

33. Harrill, R. Residents' Attitudes toward Tourism Development: A Literature Review with Implications for Tourism Planning. J. Plan. Lit. 2004, 18, 251-256. [CrossRef] 
34. Doxey, G. A causation theory of visitor-resident irritants: Methodology and research inferences. In Proceedings of the Travel and Tourism Research Associations Sixth Annual Conference Proceedings, San Diego, CA, USA, 8-11 September 1975; pp. 195-198.

35. Ko, D.W.; Stewart, W. A structural equation model of residents' attitudes for tourism development. Tour. Manag. 2002, 23, 521-530. [CrossRef]

36. Choi, H.C.; Sirakaya, E. Measuring Residents' Attitude toward Sustainable Tourism: Development of Sustainable Tourism Attitude Scale. J. Travel Res. 2005, 43, 380-394. [CrossRef]

37. Gössling, S.; Peeters, P.; Ceron, J.P.; Dubois, G.; Patterson, T.; Richardson, R. The eco-efficiency of tourism. Ecol. Econ. 2005, 54, 417-434. [CrossRef]

38. Tabatchnaia-Tamirisa, N.; Loke, M.; Leung, P.; Tucker, K. Energy and tourism in Hawaii. Ann. Tour. Res. 1997, 24, 390-401. [CrossRef]

39. Kannan, D.; de Sousa Jabbour, A.B.L.; Jabbour, C.J.C. Selecting green suppliers based on GSCM practices: Using fuzzy TOPSIS applied to a Brazilian electronics company. Eur. J. Oper. Res. 2014, 233, 432-447. [CrossRef]

40. Lin, M.H.; Hu, J.Y.; Tseng, M.L.; Chiu, A.S.F.; Lin, C.Y. Sustainable development in technological and vocational higher education: Balanced scorecard measures with uncertainty. J. Clean. Prod. 2016, 120, 1-12. [CrossRef]

41. Tseng, M.L.; Lim, K.M.; Wong, W.P. Sustainable supply chain management: A closed-loop network approach. Ind. Manag. Data Syst. 2015, 115, 436-461. [CrossRef]

42. Esquer-Peralta, J. Sustainability Management Systems (SMS): An Integrative Approach to Management Systems towards Sustainable Development. Ph.D. Thesis, University of Massachusetts Lowell, Lowell, MA, USA, 2007.

43. Wu, K.J.; Liao, C.J.; Tseng, M.; Chiu, K.K.S. Multi-attribute approach to sustainable supply chain management under uncertainty. Ind. Manag. Data Syst. 2016, 116, 777-800. [CrossRef]

44. Ranbir, A. Tourism development in Pushkar. South Asian J. Tour. Herit. 2011, 4, 37-46.

45. Sharma, Y.; Saini, S. Water Quality Status of Pushkar Lake as a Primary data for Sustainable Development. South Asian J. Tour. Herit. 2011, 4, 2.

46. Gupta, S.K.; Kumar, R.; Sunil, T. Measurement of Tourists' Perception and Satisfaction towards Tourism Development in Pushkar, Rajasthan. Wesley. J. Res. 2020, 13, 45-51.

47. Kumar, S.; Gupta, S.K.; Voda, M. Measurement of stakeholders perception and satisfaction towards Sustainable Tourism Development in Pushakr region of Rajasthan. Geogr. Tech. 2021, 16, 87-96.

48. Pritwani, K.; Kumar, N. An exploratory study to assessing the online satisfaction of foreign tourist visiting the Pushkar. South Asian J. Tour. Herit. 2011, 4, 193-205.

49. Santosh, V.; Sudha, S. Analysis of Pushkar lake water before, during and after the fair international. J. Life Sci. BioTechnology Pharma Res. 2012, 1, 35-41.

50. Kumar, R. Effect of anthropogenic activities on Indian pilgrimage sites-A case study of Pushkar Lake. Arch. Appl. Sci. Res. 2016, $8,1-7$.

51. Praveen, R. Environmental Degradation at Pushkar Valley (India) Restrain Tourism or Promote Tourism. Acta Univ. Palacki. Olomuc. Fac. Rerum Nat. Biol. 2016, 37, 117-123.

52. Prasad, S.; Bhatia, V. An empirical study of tourists' Satisfaction in the environment of pushkar fair. Int. J. Hosp. Tour. Syst. 2014, 7, 19-27.

53. Prasad, S.; Bhatia, V. Measurement of Tourist Satisfaction with Hotels in Pushkar. J. Hosp. Appl. Res. 2013, 9, 14-27.

54. Madhu, S. Pushkar And Pushkar Fair: Its Historical, Religious and Cultural Perspective. Int. J. Arts Sci. 2016, 9, $215-228$.

55. Haywood, K.M. Can the tourist area life cycle be made operational? Tour. Manag. 1986, 7, 154-167. [CrossRef]

56. Nunkoo, R.; Ramkissoon, H. Residents' Satisfaction with Community Attributes and Support for Tourism. J. Hosp. Tour. Res. 2011, 35, 171-190. [CrossRef]

57. Pearce, P.L.; Moscardo, G.; Ross, G.F. Tourism Community Relationship; Pergamon: New York, NY, USA, 1996.

58. Tosun, C. Expected Nature of Community Participation in Tourism Development. Tour. Manag. 2006, 27, 493-504. [CrossRef]

59. Friedman, H.H.; Amoo, T. Rating the Rating Scales. J. Mark. Manag. Winter 2002, 9, 114-123.

60. Kim, S.; Wong, K.K.F.; Cho, M. Assessing the economic value of a world heritage site and willingness-to-pay determinants: A case of Changdeo Palace. Tour. Manag. 2007, 28, 317-322. [CrossRef]

61. De Mooij, M. Global Marketing and Advertising; Sage: Thousand Oaks, CA, USA, 1997.

62. McGorry, S.Y. Measurement in a cross-cultural environment: Survey translation issues. Qual. Mark. Res. 2000, 3, 74-78. [CrossRef]

63. Kim, K.; Uysal, M.; Sirgy, M.J. How does tourism in a community impact the quality of life of community residents? Tour. Manag. 2013, 36, 527-540. [CrossRef]

64. Liang, Z.X.; Hui, T.K. Residents' quality of life and attitudes toward tourism development in China. Tour. Manag. 2016, 57, 56-67. [CrossRef]

65. Rivera, M.; Croes, R.; Lee, S.H. Tourism development and happiness: A residents' perspective. J. Destin. Mark. Manag. 2016, 5, 5-15. [CrossRef]

66. Yu, C.P.; Cole, S.T.; Chancellor, C. Assessing community quality of life in th context of tourism development. Appl. Res. Qual. Life 2016, 11, 147-162. [CrossRef]

67. Pham, K.; Andereck, K.; Vogt, C. Local residents' perceptions about tourism development. Travel Tour. Res. Assoc. Adv. Tour. Res. Glob. 2019, 74, 12.

68. Daniel, W.W.; Biostatistics, A. Foundation for Analysis in the Health Sciences, 7th ed.; John Wiley \& Sons: New York, NY, USA, 1999. 
69. Tabachnick, B.G.; Fidell, L.S. Using Multivariate Statistics; Allyn and Bacon: Boston, MA, USA, 2014.

70. Lankford, S.V.; Howard, D.R. Developing a Tourism Impact Attitude Scale. Ann. Tour. Res. 1994, 21, 121-139. [CrossRef]

71. Edwards, A.L. Techniques of Attitude Scale Construction; Appleton-Century-Crofts: East Norwalk, CT, USA, 1957; Volume xiii.

72. Osadebe, P.U. Construction of Valid and Reliable Test for Assessment of Students. J. Educ. Pract. 2015, 6, 51-57.

73. Kaiser, H.F.; Rice, J. Little Jiffy, Mark Iv. Educ. Psychol. Meas. 1974, 34, 111-117. [CrossRef]

74. Almeida-García, F. Analysis of tourism policy in a developing country: The case of Morocco. J. Policy Res. Tour. Leis. Events 2018, 10, 48-68. [CrossRef]

75. Cole, S. Information and empowerment, the keys to achieving sustainable tourism. J. Sustain. Tour. 2006, 14, 629-644. [CrossRef]

76. Nunkoo, R.; Smith, S.L.J.; Ramkissoon, H. Residents' attitudes to tourism: A longitudinal study of 140 articles from 1984 to 2010. J. Sustain. Tour. 2013, 21, 5-25. [CrossRef]

77. Strzelecka, M.; Boley, B.B.; Woosnam, K.M. Place attachment and empowerment: Do residents need to be attached to be empowered? Ann. Tour. Res. 2017, 66, 61-73. [CrossRef]

78. Boley, B.B.; McGehee, N.G. Measuring empowerment: Developing and validating the resident empowerment through tourism scale (RETS). Tour. Manag. 2014, 45, 85-94. [CrossRef]

79. Sofield, T.H. Empowerment for Sustainable Tourism Development; Pergamon: London, UK, 2013.

80. Joo, D.; Woosnam, K.L.M.; Strzelecka, M.; Boley, B.B. Knowledge, empowerment, and action: Testing the empowerment theory in a tourism context. J. Sustain. Tour. 2020, 28, 69-85. [CrossRef]

81. Scheyvens, R. Ecotourism and the empowerment of local communities. Tour. Manag. 1999, 20, 245-249. [CrossRef]

82. Gozgor, G.; Demir, E. The Effects of Economic Policy Uncertainty on Outbound Travel Expenditures. J. Compet. 2018, 10, 5-15. [CrossRef]

83. Wang, J.; Huang, X.; Gong, Z.; Cao, K. Dynamic assessment of tourism carrying capacity and its impacts on tourism economic growth in urban tourism destinations in China. J. Destin. Mark. Manag. 2020, 15, 100383. [CrossRef]

84. Thetsane, R.M. Local community participation in tourism development: The case of Katse Villages in Lesotho. Athens J. Tour. 2019, 6, 123-140. [CrossRef]

85. Nematpour, M.; Faraji, A. Structural analysis of the tourism impacts in the form of future study in developing countries (case study: Iran). J. Tour. Futures 2019, 5, 259-282. [CrossRef]

86. Szromek, A.; Kruczek, Z.; Walas, B. The Attitude of Tourist Destination Residents towards the Effects of Overtourism-Kraków Case Study. Sustainability 2020, 12, 228. [CrossRef]

87. Anuar, A.N.; Ridzuan, F.H.; Jaini, N.; Sulaiman, F.C.; Hashim, N.I. The impact of overtourism towards local community in heritage city. J. Tour. Hosp. 2019, 8, 406. [CrossRef]

88. Szczepańska-Woszczyna, K.; Kurowska-Pysz, J. Sustainable business development through leadership in SMEs. Eng. Manag. Prod. Serv. 2016, 8, 57-69. [CrossRef]

89. Androniceanu, A.; Tvaronavičienè, M. Developing a holistic system for social assistance services based on effective and sustainable partnerships. Adm. Manag. Public 2019, 33, 103-118. [CrossRef]

90. Dkhili, H. Environmental performance and institutions quality: Evidence from developed and developing countries. Mark. Manag. Innov. 2018, 3, 333-344. [CrossRef]

91. Masharsky, A.; Azarenkova, G.; Oryekhova, K.; Yavorsky, S. Anti-crisis financial management on energy enterprises as a precondition of innovative conversion of the energy industry: Case of Ukraine. Mark. Manag. Innov. 2018, 3, 345-354. [CrossRef]

92. Wong, P.P. Coastal Tourism Development in South East Asia: Relevance and Lessons for Coastal Zone Management. Ocean Coast. Manag. 1998, 38, 89-109. [CrossRef]

93. Meyer, D.F.; Masehla, T.M.; Kot, S. The relationship between economic growth and economic development: A regional assessment in South Africa. J. Adv. Res. Law Econ. 2017, 8, 1377-1385.

94. Brankov, J.; Penjišević, I.B.; Ćurčić, N.; Živanović, B. Tourism as a factor of regional development: Community perceptions and potential bank support in the Kopaonik National Park (Serbia). Sustainability 2019, 11, 6507. [CrossRef]

95. Harrison, D. Towards developing a framework for analysing tourism phenomena: A discussion. Curr. Issues Tour. 2007, 10, 61-86. [CrossRef]

96. Fontefrancesco, M.F. Between Change and Stability: Local Development, Tourist Offer and Local Values in Monferrato, Italy. Етноантрополошки проблеми 2019, 14, 1149-1160. [CrossRef]

97. Kirtsoglou, E.; Theodossopoulos, D. 'They are Taking Our Culture Away' Tourism and Culture Commodification in the Garifuna Community of Roatan. Crit. Anthropol. 2004, 24, 135-157. [CrossRef]

98. Fontefrancesco, M.F. Food Festivals and Local Development in Italy: A Viewpoint from Economic Anthropology; Palgrave Macmillan: London, UK, 2020.

99. Skinner, J.; Theodossopoulos, D. Introduction: The play of expectation in tourism. In Great Expectations: Imagination and Anticipation in Tourism; Berghahn Books: New York, NY, USA, 2011; pp. 1-26.

100. Tourism and the Less Developed World: Issues and Case Studies; Harrison, D., Ed.; Cabi: Wallingford, UK, 2001. 